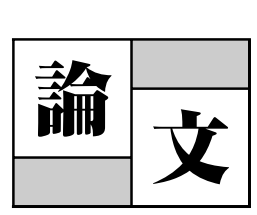

\title{
射出成形品におけるそり変形と金型温度分布との相関関係検討
}

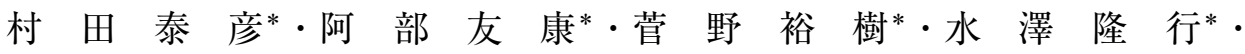 \\ 鈴 木 一 洋*·石川 和 彦*·丸山剛 史*
}

\section{Investigation on Relationship between Warpage of Injection Molded Products and Temperature Distribution in a Mold}

\author{
Murata, Yasuhiko/Abe, Tomoyasu/Sugano, Yuuki/Mizusawa, Takayuki/ \\ Suzuki, Kazuhiro/Ishikawa, Kazuhiko/Maruyama, Takeshi
}

\begin{abstract}
Warpage is a serious problem for box-shaped injection molded products. In this study, we experimentally manufactured a mold in which sheath thermo-couples are installed at each part, to measure in-mold temperature distribution for various patterns of cooling channels and core inserts made of several materials. Using the mold, we investigated the correlation between temperature distribution and warpage, and then obtained the following results ;

(1) A clear correlation between warpage and temperature difference from the movable mold and stationary one was verified.

(2) The increase in temperature difference brought about higher warpage. Furthermore, the decrease in temperature difference caused the warpage reduction by $20-30 \%$ when the arrangement patterns of cooling channels were changed.
\end{abstract}

Key words : Injection molding/Mold/Warpage/Mold temperature

\section{1. 緒言}

射出成形は，電動式射出成形機の普及や，超高速射出成

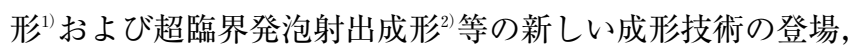
さらに，金型の微細加工技術の進歩 ${ }^{3}$ 等により，レンズ， ディスク等の光学部品や，医療・電子デバイス等の高付加 価值の精密製品の生産手段としてその用途を広げつつある それに伴い, 成形品の寸法精度や外観品質に対する要求も 益々高まっている。

射出成形品に寸法誤差をもたらす不良現象として，そり 変形が上げられる，そり変形が発生すると，製品の外観や 部品同士の組み立て等に支障をもたらすために，生産現場 において深刻な問題となっている. 本研究において対象と している箱形状の成形品では，(1)成形品コーナー部の形 状因子，（2）金型キャビティ側とコア側の温度不均一，（3） 分子配向,さらに，(4) ガラス繊維やタルク等の充填材料 では, 充填材の配向等，これらの要因が成形品の収縮状況

\footnotetext{
*日本工業大学機械工学科

埼玉県南埼玉郡宮代町学園台 4-1（７345-8501）

Nippon Institute of Technology 4-1, Gakuendai, Miyashiromachi, Minamisaitama-gun, Saitama 345-8501 Japan 2008. 3.17 受理
}

に影響を及ぼし，そり変形が発現するものと考えられてい $ろ^{4), 5)}$ ・上記 (1)，(3)，(4)の要因によるそり変形は, 樹脂 の物性やキャビティ内での樹脂流動挙動に依存して発現す るために，完全に抑止することが困難と考えられる。一方， (2)の要因によるそり変形は，3方向から樹脂の熱が移入 するコア入れ子角部では，熱が蓄積され他の部分よりも冷 却が遅れるために, 成形品角部付近の表裏に温度差が生じ, それが収縮状況に影響を及ぼし，生成されるものと考えら れている，そのため，金型温度の制御方法や金型構造等を 工夫することで抑止が可能と考えられている，そこで，温 度調節配管パターンや金型材質と，金型設定温度との関係 の検討 ${ }^{6)}$,7) , CAE 解析を利用した検討 ${ }^{8)}$ (9) 等が行われてい る.しかし，成形過程における金型内の温度分布を詳細に 計測して, 実際の温度分布とそり変形との相関関係を実証 的に明らかにした報告は見あたらず，金型設計理論の体系 化に向けての障害となっている.

このような現状から, 本研究では, シース熱電対を各部 に埋設した箱形状成形品の金型を設計・製作し，コア入れ 子内の温度調節配管パターンとコア材質を変化させた場合 における，金型内温度分布を計測し，成形品のそり量との 相関関係について検討を行った. 


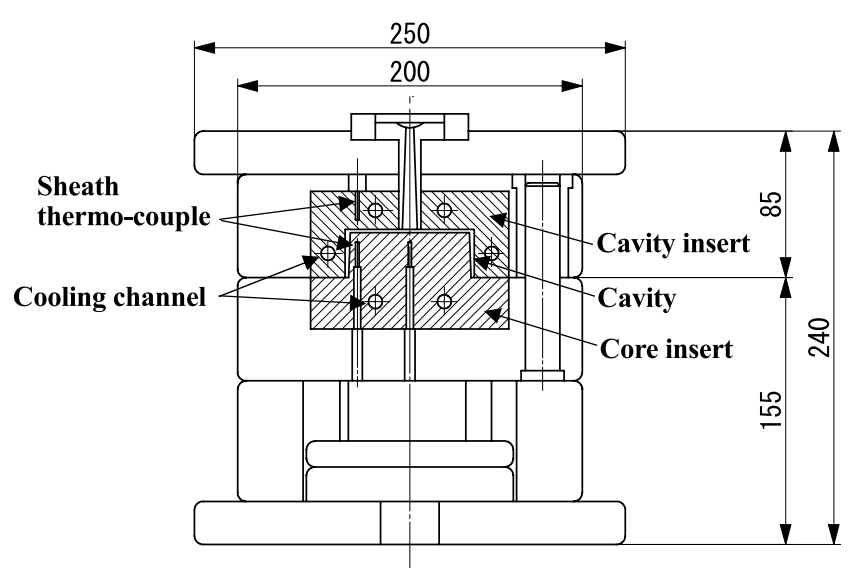

Fig. 1 Basic structure of a mold for measurement (units : mm)

\section{2. 実験方法}

\section{1 金型および入れ子の基本構造}

図 1 は，本論文で，設計・製作した金型温度分布計測用 金型の基本構造を示している. 本金型では,ダイレクトゲー トの設けられたキャビティ入れ子とコア入れ子の交換が可 能な構造となっている. 成形品形状は, 長さ $100 \mathrm{~mm} \times$ 幅 $75 \mathrm{~mm} \times$ 高さ $28 \mathrm{~mm}$, 厚さ $2 \mathrm{~mm}$ の箱形状である.

入れ子の基本構造と金型温度調節のための配管パターン を図 2 に示す。また，金型温度分布を計測するためのシー 入熱電対の設置位置を図 3 に示す.まず，(1)のキャビティ 入れ子は, 材質を機械構造用炭素鋼 S 55 C として, 入れ 子長手方向に平行に, ストレートの配管が 4 本設けられて いる. コア入れ子は, 材質を S 5 C C として，(2)のストレー ト型，(3)のコアの形状に沿って配管が折れ曲がったベン 卜型，(4)の配管穴内にバッフルプレート（仕切板）を挿 入したバッフルプレート型の 3 種類を製作した. キャビ ティおよびコア入れ子には, 直径 $1.6 \mathrm{~mm}$ の $\mathrm{K}$ タイプ（ア ルメル・クロメル）のシース熱電対を扱入するための穴を 3 ケ所ずつ設けた。 シース熱電対は，コア入れ子の表面か ら $5 \mathrm{~mm}$ 離れた箇所に測定点が位置するよう，また，図 3 に示すようにキャビティ入れ子とコア入れ子が組み合わさ れた際に，互いに対向する位置 (1)と (6)，(2)と (5)，(3)と(4)) に設置した。シース熱電対と抻入穴の隙間には，熱交換パ イプ用グリスを満たした。

本論文では，コア入れ子の材質の影響についても検討を 行った。表 1 にコア入れ子の材質と熱伝導率を示す. 配管 パターンはバッフルプレート型として，S 55 C の他に銅製， アルミニウム製, さらに, 図 4 に示すような, S 55 Cをべー スとしてコアの 4 角に銅がインサートされた入れ子（以後， 銅インサートと呼称する）を製作した。

\section{2 成形条件}

本実験の成形条件を表 2 に示す。樹脂は，日本ポリプロ 侏製のポリプロピレン MA 1 B を用いた。本論文では，樹 脂温度㧍よび設定射出率，保圧条件を一定として，金型温 度調節機の冷却水の設定温度 (以後, 金型設定温度と呼称 する）を 3 通りに変化させて計測実験を行い，それぞれの 条件が，金型温度分布およびそり変形に及ぼす影響の検討

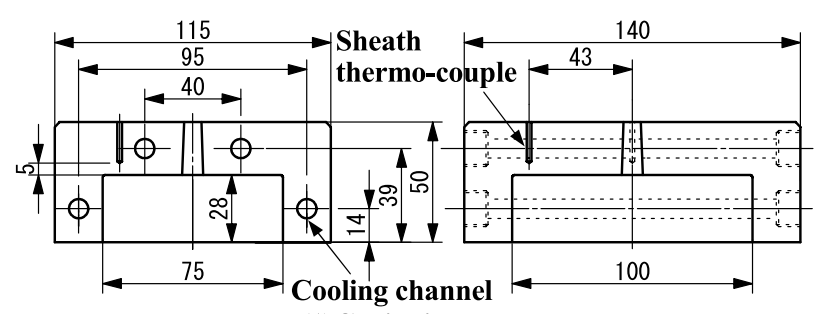

(1)Cavity insert block

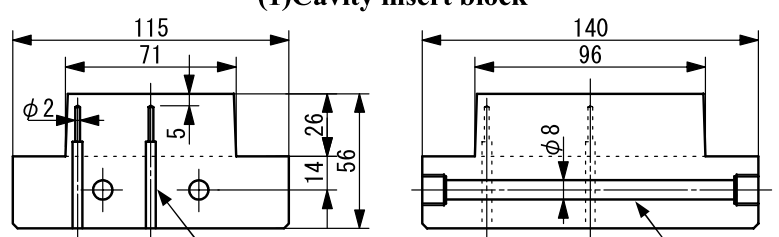

30.5 Sheath thermo-couple (2)Straight type core insert block
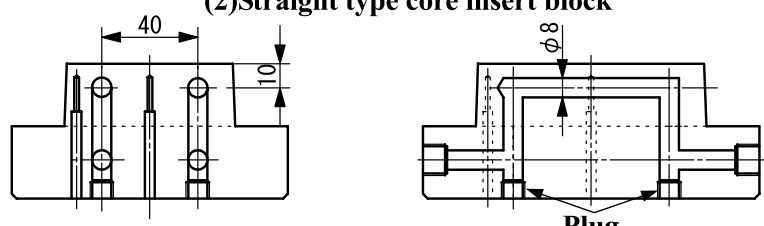

(3)Bent type core insert block
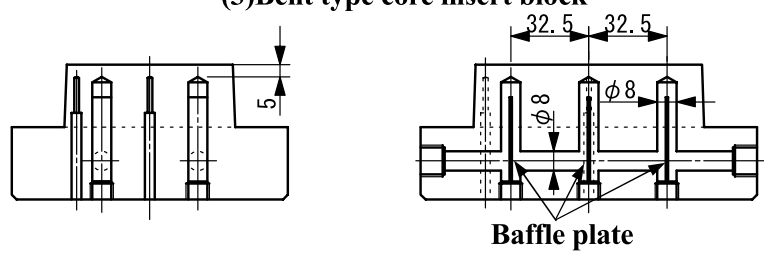

(4)Baffle plate type core insert block

Fig. 2 Basic structure of insert block and arrangement patterns of cooling channels (units: $\mathrm{mm}$ )

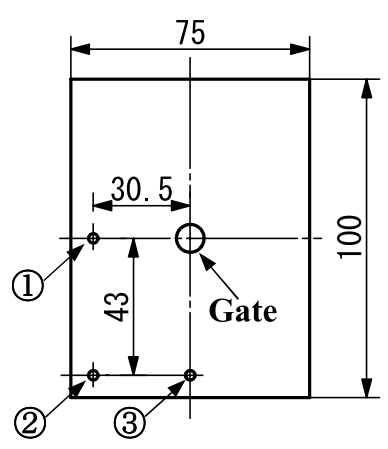

(1)Cavity side

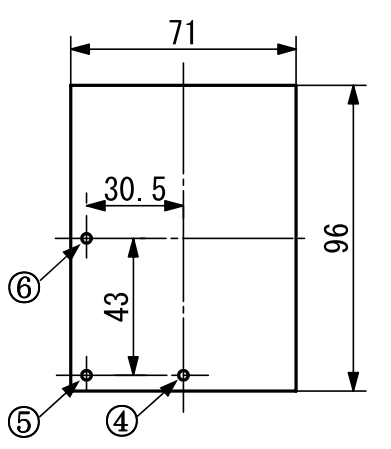

(2)Core side
Fig. 3 Insertion position of sheath thermo-couples (units : mm)

Table 1 Material of core insert block

\begin{tabular}{c|c|c}
\hline No. & Material & Thermal conductivity $(\mathrm{W} / \mathrm{m} \cdot \mathrm{K})$ \\
\hline 1 & Steel & 50 \\
\hline 2 & Copper & 403 \\
\hline 3 & Aluminum & 236 \\
\hline 4 & Copper insert & - \\
\hline
\end{tabular}


を行った．実験に用いた金型温度調節機は，株松井製作所 の最大流量 $60(\mathrm{l} / \mathrm{min})$ の $\mathrm{MCIII}-60 \mathrm{HL}$ である。計測実験 は，40 ショットの連続成形を行い，その間のシース熱電 対出力を記録した。射出成形機は，ファナック株製の最大 型締力 $490(\mathrm{kN})$ の ROBOSHOT S-2000 i 50 A を使用した。

\section{3 そり変形および密度の測定方法}

図 5 は, 成形品におけるそり変形量の定義と, 成形品の 密度測定位置を示している，本成形品では，内側方向への そり変形が生成された。本論文では，各種条件で成形され た 40 ショットの成形品の I 面と I' 面, II 面と II ' 面の 外形寸法 $\mathrm{L}_{1}, \mathrm{~L}_{2}$ を，ノギスを用いて測定し，図中の式に よりそり変形量を導出した. また, 成形品密度の検討を行っ た. 比重計 SP-1 M (Chyo Balance Corporation) を用い て，図 5(2)に示す I 面の A 部と II 面の B 部の比重をそれ

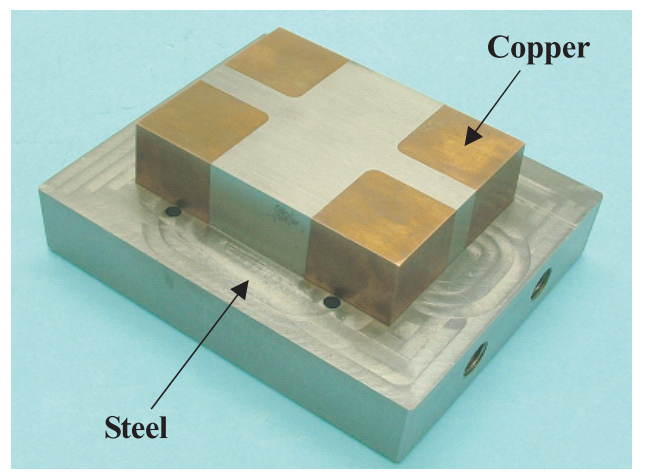

Fig. 4 Appearance of copper insert core block

Table 2 Molding conditions

\begin{tabular}{|c|c|}
\hline Cylinder temperature & $200-200-200-180-50^{*}$ \\
\hline Mold setting temperature $\quad\left({ }^{\circ} \mathrm{C}\right)$ & $30 / 50 / 70$ \\
\hline Set-up injection rate & 53.1 \\
\hline Holding pressure & 60 \\
\hline Pressure holding period & 14 \\
\hline Cycle time & 38 \\
\hline
\end{tabular}

*) Nozzle-Metering-Compression-Feed-Hopper
ぞれ測定し，密度に換算した。

\section{3．実験結果および考察}

\section{1 金型温度の経時変化}

3 通りの配管パターンのコア入れ子において，金型設定 温度を $30^{\circ} \mathrm{C}$ とて得られた 40 ショットの温度プロファイ ルの中から，21 ショット目を抽出して図 6 に示す。流動・ 保圧・冷却の各工程を明確にするために, 成形機から出力 された射出率および射出圧力信号を併記した。配管パター ンや入れ子材質の違いにより，成形開始前に，コア側の温 度がキャビティ側よりも $2^{\circ} \mathrm{C}$ 程度高くなることを確認して おり, 以後では，この初期温度差が予め存在することを考 慮して議論を行うこととする，まず，流動過程では，金型 温度はほとんど変化せずに，保圧過程に入って上昇を始め る.しかし，すべての配管パターンにおいて，(1)から(3)の キャビティ側よりも，(4)から6)のコア側の温度が高くなっ ている. 特に，コア入れ子角部の(5)で計測された温度が最 も高くなっている. ストレート型では, 射出開始直前のコ ア側の温度がキャビティ側に比べて最高 $10^{\circ} \mathrm{C}$ 高くなって おり，他の配管パターンに比べて冷却効率の低さを表して いる. なお，金型設定温度 50 と $70^{\circ} \mathrm{C}$ においても同様の傾 向を確認している.

バッフルプレート型配管を有する各種材質のコア入れ子 において, 金型設定温度を $30^{\circ} \mathrm{C}$ として得られた, 19 ショッ ト目の温度プロファイルを図 7 に示す. S 55 C では, 全過 程を通じて，(1)から(3)のキャビティ側よりも(4)から6のコ ア側の温度が高く上昇している，一方，銅，アルミニウム， 銅インサートの場合では, S 55 C と比べて, 上記コア側の 温度の上昇が小さい. 特に, 銅では, 温度上昇が最も小さ くなっている. なお, この傾向は, 金型設定温度 50 と $70^{\circ} \mathrm{C}$ の場合においても同様に確認している.

\section{2 配管パターンおよび金型材質と金型温度との関係}

各種コア入れ子において得られた 40 ショットの温度プ ロファイルから, 各ショットにおける温度の最高值（以後, ピーク温度と呼称する）を抽出して，ショット回数との関 係として整理して図 8 に示す。なお，ピーク温度は，(5)が 最高值を示す時刻における，それぞれのセンサの出力を読

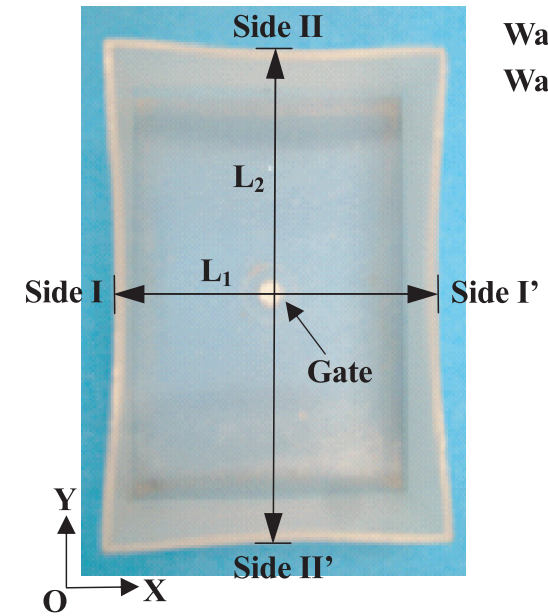

(1)Definition of warpage
Warpage in $\mathrm{X}$-direction $=\left(71-\mathrm{L}_{1}\right) / 2$

Warpage in Y-direction $=\left(96-\mathrm{L}_{2}\right) / 2$

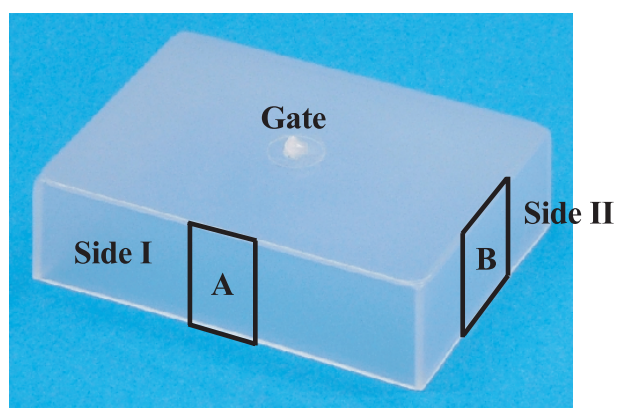

(2)Measurement portion of density

Fig. 5 Definition of warpage and measurement portion of density in box-shaped molded product 


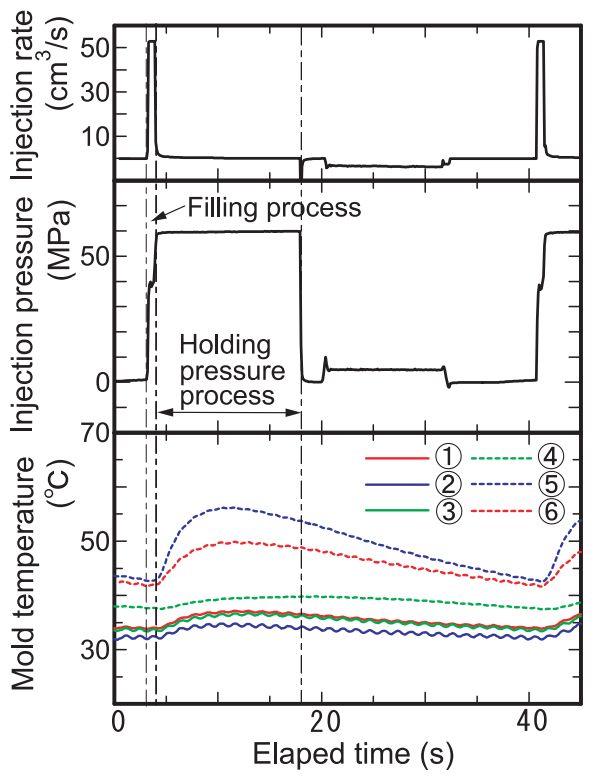

(1)Straight type

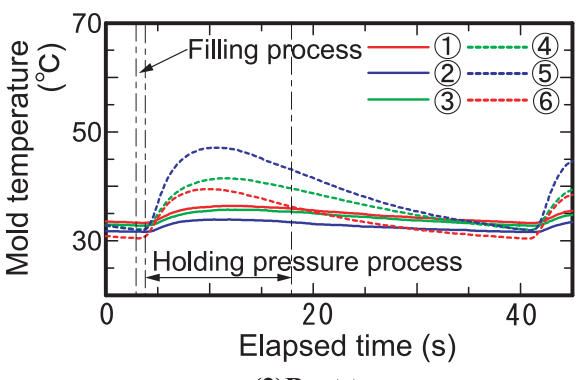

(2)Bent type

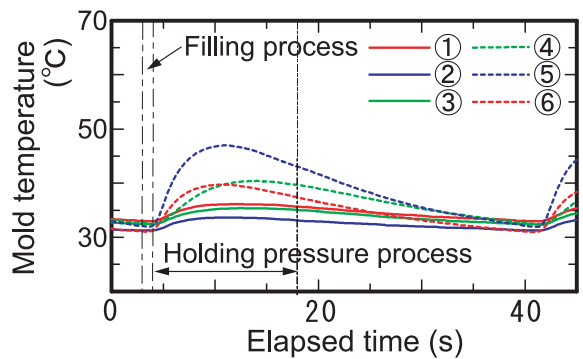

(3)Baffle plate type

Fig. 6 Mold temperature profiles measured in various arrangement patterns of cooling channels (Steel, Mold setting temperature $: 30^{\circ} \mathrm{C}$ )

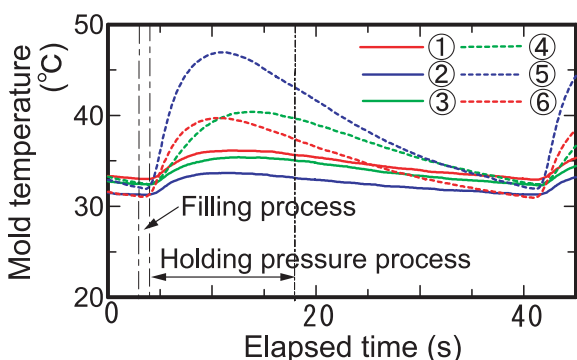

(1)Steel

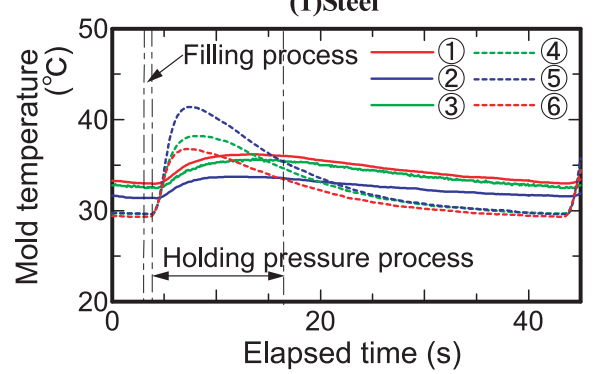

(3)Aluminum

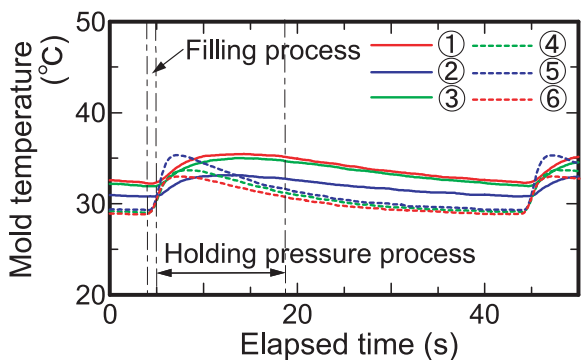

(2)Copper

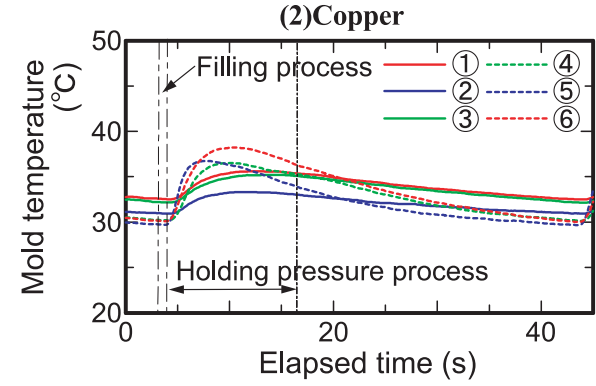

(4)Copper insert

Fig. 7 Mold temperature profiles measured in core block of various materials (Baffle plate type, Mold setting temperature : $30^{\circ} \mathrm{C}$ )

み取った。ここでは，キャビティ側とコア側のピーク温度 差が最も大きくなった(2)と(5)の, 金型設定温度 $30,70^{\circ} \mathrm{C}$ の結果を揭げた。配管パターンおよび材質を変化させた場 合に, S 55 C のストレート型において， 1 ショットから 10 ショットにかけて, $3{ }^{\circ} \mathrm{C}$ 程度の上昇が見られる以外は, 40 ショットを通じて, ピーク温度の大きな変動は見られない. また, キャビティ側(2)のピーク温度は, 配管パターンおよ びコア入れ子材質を変化させても, 最高 $2^{\circ} \mathrm{C}$ の差異しか見 られない. 一方, コア側(5)では, キャビティ側(2)に比べて ピーク温度が高くなっている. (1)の配管パターンを変化
させた場合では，ストレート型においてピーク温度差が $20^{\circ} \mathrm{C}$ 前後と最も大きく, 一方, ベント型とバッフルプレー 卜型では $15^{\circ} \mathrm{C}$ 前後と小さい. また，(2)の材質を変化させ た場合では，S 55 Cのように熱伝導率の最も低い材質では， キャビティ側とコア側とのピーク温度差が最も大きく, そ して, アルミニウム, 銅インサート, 銅の順に熱伝導率が 増加するのに伴い, ピーク温度差が減少している.

キャビティ側とコア側のピーク温度差を詳しく検討する ために，バッフルプレート型において得られた(1)と(6), (2) と (5), (3)と(4)の温度比較を図 9 に示す.ここでは, 金型設 


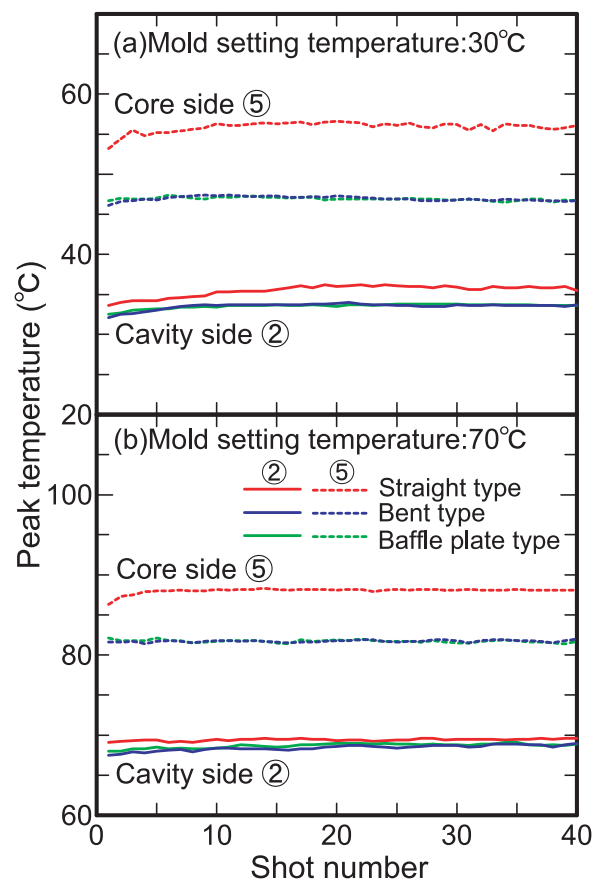

(1)Influence of cooling channel pattern (Steel)

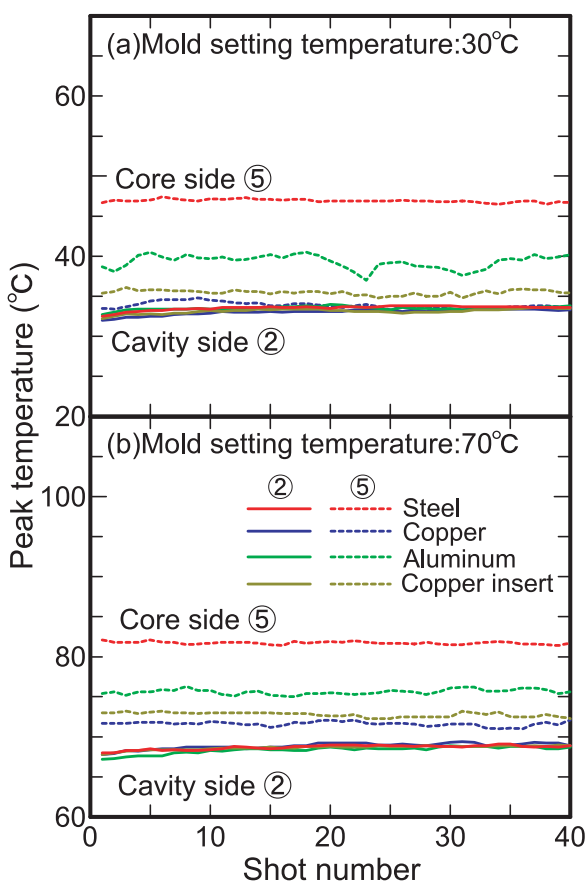

(2)Influence of core block material (Baffle plate type)

Fig. 8 Relationship between peak temperature and shot number in various arrangement patterns of cooling channels and core insert blocks made of various materials

定温度 $30^{\circ} \mathrm{C}$ の結果のみを掲げた. (2)と(5)のピーク温度差 が最も大きく，例えば，S $55 \mathrm{C} て ゙ は ， 15^{\circ} \mathrm{C}$ 程度と最も大 きい.一方，(1)と(6)よび(3)と(4)で小さく，例えば，S 55 $\mathrm{C}$ では, $5{ }^{\circ} \mathrm{C}$ 程度で(2)と(5)の場合に比べて $1 / 3$ 程度となっ ている. なお，この傾向は，金型設定温度 50 と $70^{\circ} \mathrm{C}$ の場 合においても同様に確認している.

\section{3 配管パターンおよび金型材質とそり変形量との関係}

図 10 は, 金型設定温度 30 および $70^{\circ} \mathrm{C}$ の場合に, 各種 コア入れ子において得られた 40 ショットの成形品の X 方 向と $\mathrm{Y}$ 方向のそり変形量を示している. まず， 1 ショット から 40 ショットにかけて，ばらつきが見られるものの， そり変形量の大きな変化は見られない. S 55 C のストレー 卜型でのそり変形量が最も大きく, バッフルプレート型が 相対的に小さくなっている. また, 各種材質でのそり変形 量を比較すると, 銅, アルミニウムのように熱伝導率が高 いものほど，そり変形量が小さくなっている.

\section{4 金型温度とそり変形量との関係}

キャビティ側とコア側との温度差とそり変形量との相関 関係の検討を行う。まず，各種コア入れ子における 40 ショットの連続成形において記録されたすべての温度プロ ファイルから, 平均值を計算し, コア側とキャビティ側の 差 (以後, 平均温度差と呼称する) を求めた。 また, 図 10 の 40 ショットの成形品のそり変形量の平均值を求めた. そして, 得られた各種コア入れ子における, キャビティ側 (2)とコア側(5)の平均温度差と, 平均そり変形量との関係を 図 11 に示す.（1）の X 方向では, 平均温度差の増加に伴 い, 平均そり変形量が増加している. 一方, (2)の Y 方向 では, 銅を除いて, $\mathrm{X}$ 方向と同様に, 平均温度差の増加に
伴い, 平均そり変形量が増加している. これは, 平均温度 差の増加に伴い, 成形品角部分のキャビティ側とコア側の 収縮率に差異が生じ, その結果, そり変形量が大きくなる ためと推察される. 最も平均温度差が大きくなった S 55 C のストレート型での平均そり変形量を基準とすると, 配管 パターンや材質を変更して平均温度差を $0{ }^{\circ} \mathrm{C}$ に調節するこ とによって，そり変形量が $20 \sim 30 \%$ 改善されることがわ かる.

\section{5 そり変形と成形品密度との関係}

図 11(2)において，銅製コア入れ子では，平均温度差が 最も小さいにも関わらず, $\mathrm{Y}$ 方向の平均そり変形量がアル ミニウム, 銅インサートの場合に比べて, 若干大きくなる 特異な現象が確認された. ここでは, その原因について考 察する. 各種材質のコア入れ子において, 金型設定温度 $50^{\circ} \mathrm{C}$ で得られた成形品から, 図 5 の I 面の $\mathrm{A}$ 部と II 面の $\mathrm{B}$ 部の密度を測定した結果を図 12 に示す。銅以外の材質 では, I 面とII 面の密度がほほ同じ值を示すのに対して, 銅では，I 面に比べて II 面の密度が小さくなっている．銅 では，熱伝導率が最も高いために，コア入れ子の冷却効率

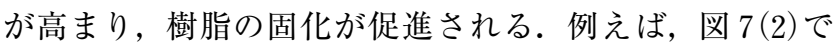
見られた, コア側の温度が他の材質ほど上昇しない傾向が, これを裏付けている. そのため, 保圧過程において, ゲー トから遠く離れて固化が進行する II 面と II '面よりも, ゲー トから近い I 面と I ' 面へと樹脂が選択的に流入し， II 面 と II ' 面の密度が小さくな. その結果, I 面と I , 面よ りも， II 面と II ' 面の成形収縮が大きくなり, そり変形量 が増加したものと推察される. なお, PP は結晶性樹脂で あるため, 緩やかに冷却される I 面と I ' 面では, II 面と 


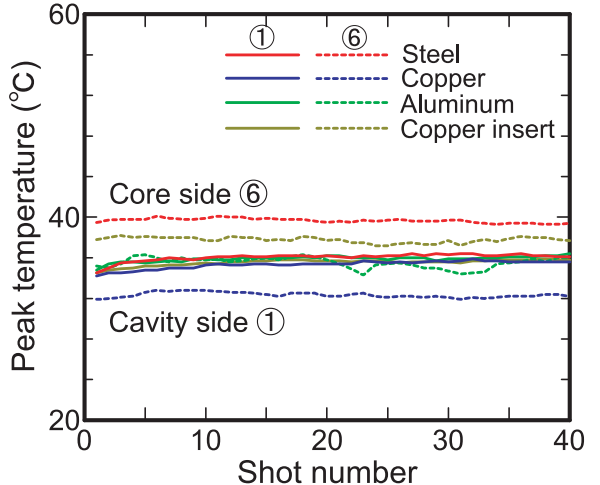

(1)Position (1)-(6)

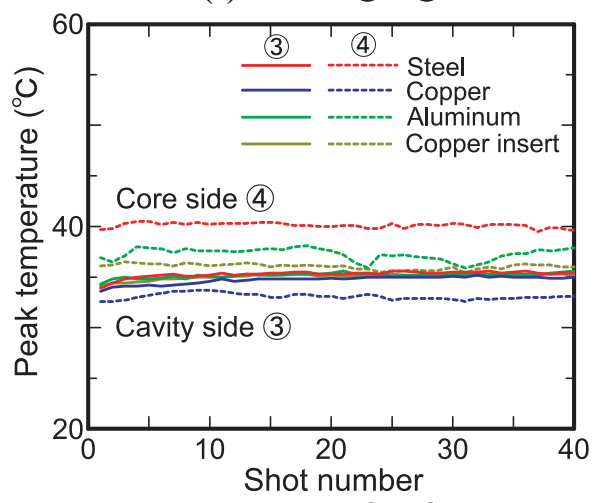

(3)Position (3)-(4)

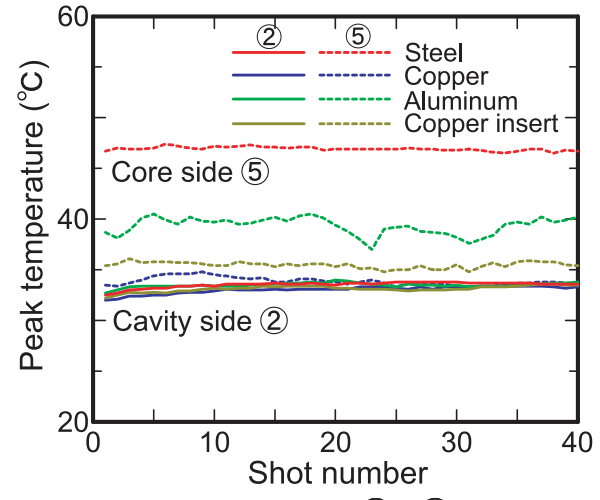

(2)Position (2)-(5)

Fig. 9 Relationship between peak temperature and shot number in each measurement position (Baffle plate type, Mold setting temperature : $30^{\circ} \mathrm{C}$ )

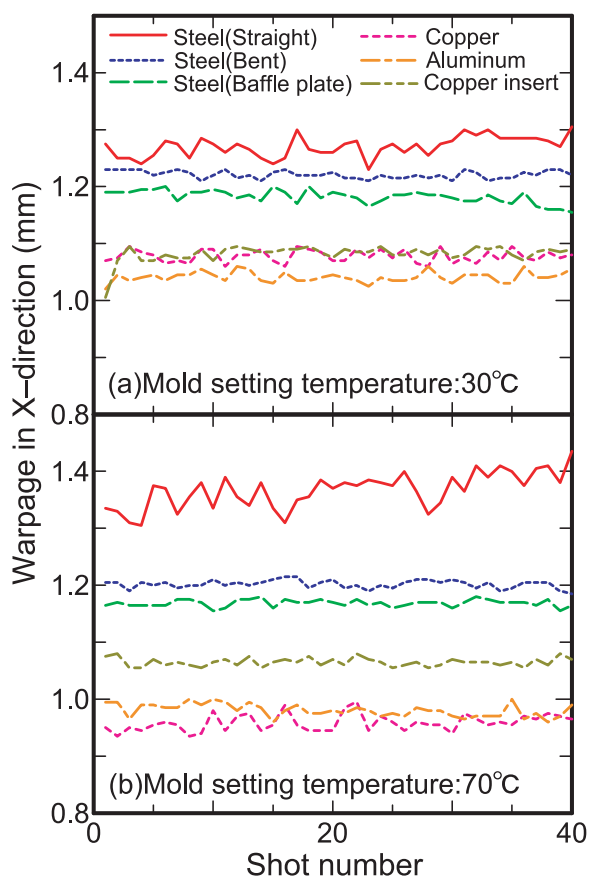

(1)X-direction

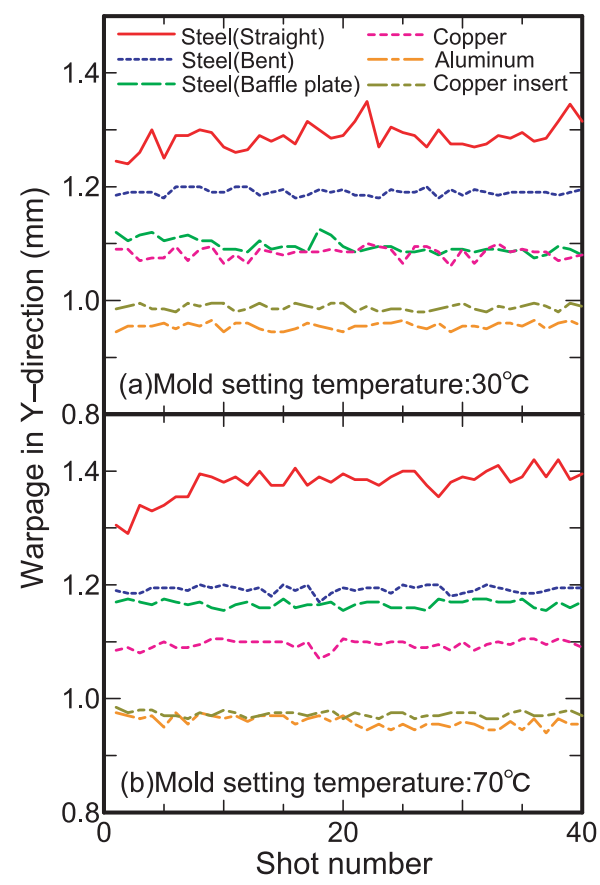

(2)Y-direction

Fig. 10 Relationship between warpage and shot number in various arrangement patterns of cooling channels and core insert blocks of various materials

II '面に比べて結晶化度が増加し, その結果, I 面と I' 面の成形収縮が逆に大きくなるものと考えられた。しかし， 上記結果から, この場合では, 冷却速度差によって生じる 密度差よりも, 保圧過程での補償流動に基づく圧力負荷状 況の違いによる密度差の方が, そり変形に大きく影響した
ものと推察される.

\section{4. 結言}

コア入れ子の温度調節配管パターンと材質を変化させた 場合における，金型温度分布と成形品のそり変形量との相 


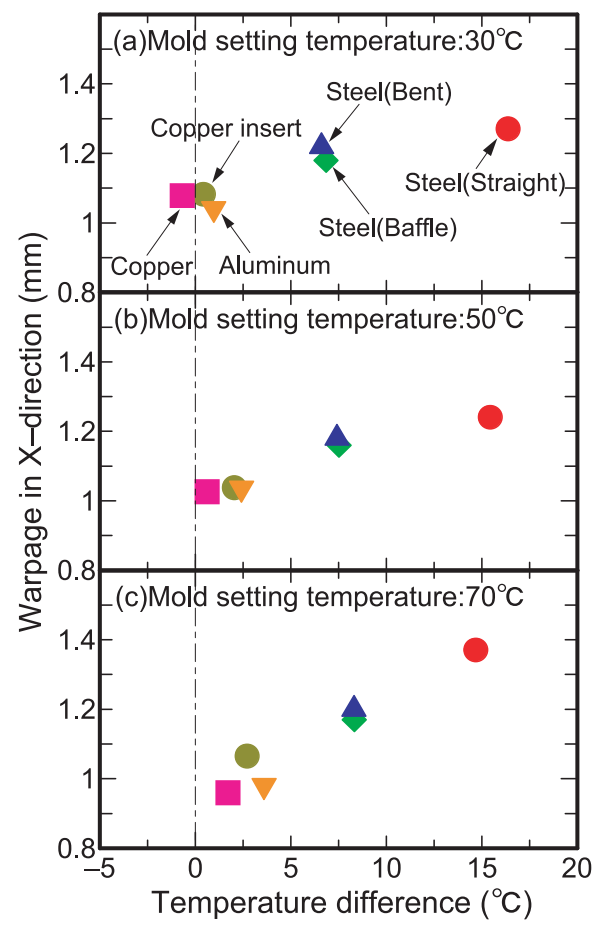

(1)X-direction

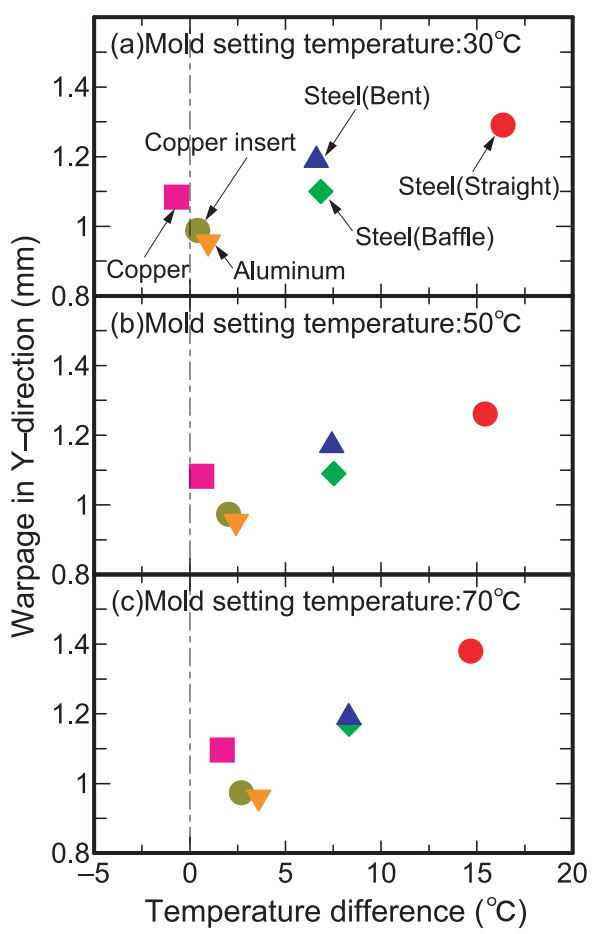

(2)Y-direction

Fig. 11 Relationship between warpage and temperature difference in various arrangement patterns of cooling channels and core insert blocks made of various materials

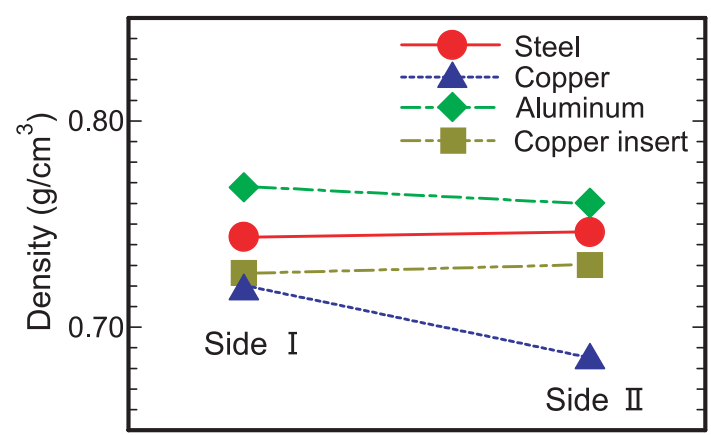

Fig. 12 Density values at various portions of molded products (Baffle plate type, Mold setting temperature : $50^{\circ} \mathrm{C}$ )

関関係について検討を行った，得られた結果を以下に列記 する。

（1）配管パターンを変化させた場合では，ストレート型に おいて，キャビティ側とコア側との温度差が最も大き くなり, ベント型とバッフルプレート型が小さくなる.

（2）コア入れ子材質を変化させた場合では, 熱伝導率の増 加に伴い, キャビティ側とコア側との温度差が減少する

（3）そり変形量は，ストレート型で最も大きく，バッフル プレート型が相対的に小さくなる．また，コア入れ子 材料の熱伝導率の増加に伴い，そり変形量が減少する。

（4）キャビティ側とコア側との温度差の増加に伴い, そり 変形量が概ね増加する。配管パターンやコア入れ子材 質を変更して温度差をなくすことによって，そり変形 量が 20〜 30\% 低減される.

（5）銅のようにコア入れ子の冷却効率が高い場合には，成
形品の密度が局部的に変化し，キャビティ側とコア側 の温度差が小さいにも関わらず，そり変形量が大きく なることがある.

以上のように, 金型温度分布とそり変形量との間に明確 な相関関係があることを，計測を用いて実証的に明らかに した．本論文で得られた知見は，箱形状成形品のそり変形 の抑止に対して，具体的な指針を与えるものと考えられ， 今後の活用が期待される.

おわりに，射出成形機および金型温度調節機を貸与下 さった(株)サン精密化工研究所，(株松井製作所，さらに，樹 脂を提供下った株)三菱化学科学技術研究センターに謝意を 表します.

\section{参 考 文 献}

1 ）廣恵章利編：超高速射出成形技術，154(1999), 三光 出版社

2 ）津田文朗 : 成形加工，13(2)，83(2001)

3 ) 早乙女康典：精密工学会誌，69(9)，1221(2003)

4 ) Takahara, T., Yoshinaga, M. and Mizuno, T. : 2005 SAE International, 05 AC-45 (2005)

5 ）高原忠良, 古橋 洋, 前田秀典, 井八山達也, 小山清 人：成形加工, $20(3), 193(2008)$

6 ）高橋重晶, 関野英一郎, 小林博行 : 成形加工 ' 96,145 (1996)

7 ）高橋重晶, 関野英一郎, 小林博行 : 成形加工 ' 97,311 (1997)

8 ）多田和美：成形加工，10(5)，298(1998)

9 ）大井秀人：成形加工，14(9)，566(2002) 